\title{
Internet of Things (IoT) in Agriculture: The Idea of Making the Fields Talk
}

\section{Siddhartha Vadlamudi}

Software Engineer II, Xandr, AT\&T Services Inc., New York, US

*Corresponding Contact:

Email: vadlamudisiddhartha@gmail.com

\begin{abstract}
The demand for agricultural crops is moving at a slower pace compared to the human population. There must be increased agricultural productivity. Ongoing innovative advances have added to the ascent of exactness agribusiness, empowering farmers to settle on better choices with more data about their soil, water, yield, and local environment, yet has been generally restricted to popularized and production of cash crops. The objective of smart agribusiness research is to ground a dynamic emotionally supportive network for the management of farms. IoT is being used in agriculture to get to know the crop field by utilizing sensors for monitoring, controlling in the field. It is used to get to know the crop field by utilizing sensors for monitoring, controlling in the field, etc. Recent developments in IoT, comparison between traditional and smart agriculture, and the roles of IoT in agriculture were analyzed in this study. The articles were purposively inspected while the qualitative data gathered was dissected utilizing content analysis. Summarily, the rise of smart agriculture has lowered the practice of traditional farming, as it has enhanced it in no small way. The research likewise showed that the lacuna in agriculture can be filled with IoT. Scalability in technology should be encouraged without affecting the functionalities of the existing infrastructures.
\end{abstract}

Key words:

Agriculture, Innovation, Internet of Things, Sensor, Scalability

$12 / 20 / 2020$

Source of Support: None, No Conflict of Interest: Declared

This article is licensed under a Creative Commons Attribution-NonCommercial 4.0 International License.

Attribution-NonCommercial (CC BY-NC) license lets others remix, tweak, and build upon work non-commercially,

and although the new works must also acknowledge \& be non-commercial.

\section{INTRODUCTION}

Around 1 billion individuals over the world are associated with agriculture, and albeit there is a reduction in the number of farmers, the request for farming yields is supposed to be times two as the total populace arrives at 9 billion in 2050 (Antony et al, 2020). This will demand for an expansion in horticultural efficiency, particularly from low and middle income nations (LMICs). Present innovative advances have added to the ascent of exactness 
agriculture, empowering farmers to settle on better choices with more understanding as touching their dirt, water, yield, and local environment (Gray, 2018; Ayaz, 2019). In any case, taking up these advances has been restricted to business scale and cultivation of cash crop (BBC, 2019). Smart Agriculture is a rural administration idea utilizing current innovation to expand the amount and nature of agricultural items. In the 21st century, farmers made use of GPS, soil examining, management of data, and Internet of Things advancements. The objective of smart agribusiness research is to ground a dynamic emotionally supportive network for the management of farm. Smart agriculture will enable farmers to use their lands efficiently, make processes faster and agile, use fertilizers and pesticides in a controlled quantity, gain a maximum yield, have insights, make predictions and analyze risks for further use based on previous data etc (Ratnaparkhi et al, 2020).Smart cultivating considers it significant to address the issues of populace development, environmental change and work that has acquired a ton of mechanical consideration, from planting and watering of yields to the wellbeing and harvesting (Srivastava, et al 2020).

The far and wide of the web from the most recent twenty years has brought limitless advantages for associations and residents over the world. The significant advantage of this advancement was the capacity to make and purchase services progressively. As of late, Internet of Things (IoT) is hoping to give similar advantage through its creative advancements and giving an approach to improve the client's insight and capacity by changing the workplace (Farooq et al, 2020). IoT offers numerous arrangements in various areas like medical services, retail, traffic, security, keen homes, smart urban communities, including agriculture (Donepudi, 2020). IoT arrangement in farming is viewed as the ideal way out on the grounds that in this sector there is a requirement for ceaseless checking and controlling. In agriculture, IoT is utilized at various levels in the agribusiness mechanical creation chain (Medela et al, 2013).

IoT is being utilized in agribusiness to become more acquainted with the yield field by using sensors for checking and controlling in the field (Sales et al, 2015). IoT gives a system to detect an item in a controlled climate by presenting a distantly gotten network foundation. It sets out open doors to beat the extension hole between the actual world and PC based frameworks (Donepudi et al., 2020). The fundamental advantage of presenting the IoT in farming is to improve the proficiency and precision with low-level human-mediation. IoT modernization helps in gathering of the data on elements like weather, dampness, temperature and the soil's productivity, crop electronic examination engages recognizable proof of wild plants, water level, bug area, horticulture, and so on (Muthnoori and Munaswamy, 2019). The fundamental utilizations of IoT in horticulture are Exact Farming, Livestock, and Greenhouses, which are gathered into various observing areas.

\section{Statement of Problem}

To enhance the produce of agriculture with less assets and work endeavors, significant developments have been made all through mankind's set of experiences. By and by, the high rate of populace would not allow the demand and supply connect amidst these occasions. As indicated by the figures forecasted in 2050, the total populace is proposed to be 9.8 billion, an increment of roughly $25 \%$ from the present figure (Ayaz et al, 2019). This brings up the issue of taking care of to this expanded populace. For this expanded amount and nature of the harvest yield is fundamental. This need can be satisfied by the utilization of proficient and keen advances in the farming cycles. Additionally, thinking about the customary cultivating methods, farmers need to visit the agribusiness sites regularly all 
through the span of the crop to have a superior thought regarding the harvest conditions. For this, the need of keen agribusiness emerges, as $70 \%$ of cultivating time is spent observing and understanding the states of the crop as opposed to accomplishing genuine field work (S. Navulur et al, 2017).

As of late, the Internet-of-Things (IoT) is starting to affect a large exhibit of areas and ventures, going from production, wellbeing, correspondences, and energy to the agriculture business, to diminish failures and improve the outcome over all business sectors (E. Sisinn et al, 2018). In the case of looking carefully, one feels that the present applications are just starting to expose what's underneath and that the genuine effect of IoT and its uses are not yet seen. In any case, thinking about this advancement, particularly in the recent past, we can anticipate that IoT advances will assume a vital part in different uses of the agriculture area. This is a direct result of the capacities given by IoT, which includes the fundamental correspondence foundation and scope of administrations, like nearby or distant information procurement, cloud-based savvy data investigation and making decision, client interfacing, and agribusiness activity mechanization. Such abilities can change the industry of agriculture which is likely one of most ineffective areas of our financial worth chain presently (] O. Elijah et al, 2018).

\section{Research Questions}

- What are the recent developments in Internet of Things (IoT)?

- What is the contrast between Traditional and Smart Agriculture?

- What is the role of Internet of Things (IoT) in Smart Agriculture?

\section{Objectives of the study}

The main objective of the study is to determine the effect of Internet of Things (IoT) in Smart Agriculture: Towards Making Fields Talk.

- $\quad$ To examine present advancements in Internet of Things (IoT).

- To make comparison between Traditional and Smart Agriculture.

- To assess the role of Internet of Things (IoT) in Smart Agriculture.

\section{Justification of Study}

This study centers around more intelligent, better and more effective crop developing innovation needed to fulfill the increasing demand for food of the expanding total populace in one period of the always contracting arable land. Discoveries from this exploration are for advancement of farmers to give framework which use advances accommodating for expanding the farming yield. The improvement of new strategies for improving harvest yield and managing, one can promptly see the current innovation inventive for the individuals who consider cultivating to be a calling, following the harvest development, security and nourishment naming organizations between cultivators, providers, retailers and purchasers. The use of innovation in the aspect of farming assumes an essential part in increasing the production just as in decreasing the labor.

By carrying out the most recent detecting and IoT advances in farming methods, each part of the conventional cultivating strategy can be changed on a very basic level. In the farming area, consistent joining of remote sensors and the IoT in brilliant horticulture will raise agribusiness to levels which were beforehand incomprehensible. By following the acts of smart agribusiness, IoT can assist with upgrading the arrangements of the numerous 
conventional cultivating problems, similar to reaction of drought, yield improvement, land reasonableness, water system, and vermin control. This research is additionally useful to scholars, experts, and makers of decision working with rural establishments and different people who are executing IoT based advancements for brilliant cultivating.

\section{LITERATURE REVIEW}

Agriculture is the main supplier of food and assumes a fundamental part in economic development. Farming is seen as the premise of life for the human species as it is the principle wellspring of food crops and other crude materials. It takes up principal aspect in the advancement of country's economy. It also provides large abundant work freedoms to individuals. Advancement in rural area is important for the enhancement of financial state of the country (Ahmed et al., 2020). Unfortunately, a lot of farmers actually utilize the conventional strategies for cultivating which brings about low yielding of harvests and natural products. In any case, any place mechanization had been carried out and people had been supplanted via programmed hardware, the crop has been enhanced. Thus there is need to execute current science and innovation in the agribusiness area for expanding the crop (Vadlamudi, 2016). As typified in the Bank's 2015 Agenda for the Global Food System, CSA's problem of advancing triple-win way outs includes discovering approaches to interface farmers more emphatically into business sectors, advance the improvement of new biotechnologies fit to CSA objectives, and assemble public foundations to merge the two (World Bank, 2015).

It is noteworthy that the agricultural industry uses approximately $70 \%$ of accessible fresh water for Sustainable Food and Agriculture by FAO, (Ayaz et al., 2019). This percentage is higher in countries like Brazil, where the percentage used by this industry is $75 \%$ and even much higher in some underdeveloped countries, even it exceeds 80\% (Olivera et al., 2017). This is a result of the checking system, as at 2013, crops visual examination for water system decisions was normal, as almost $80 \%$ of ranches in United States were seen through this. Yield monitoring is considered an essential part of precision farming both before and during the time of harvest. The quality of crops relies upon these elements to mention a few: adequate fertilization with great quality dust particularly when anticipating yields of seeds under changing natural conditions (Wietzke et al., 2018; Chung et al., 2016)

By and by, when managing more open business sectors, purchasers all over the planet become more specific about organic product quality; henceforth, viable creation relies upon the correct organic product size to the perfect market at the perfect time (Ayaz et al., 2018). The achievement and creation of different harvests under such controlled climate rely upon numerous components which include: precision of checking boundaries, design of shed, covering material to control wind impacts, ventilation framework, choice supportive system, and so on. A definite examination is given in (Shamshiri et al. 2018), where every of these components, their effects, and how remote sensors can help for this are thought of. Exact checking of climate boundaries is the most basic assignment in current nurseries, where a few estimation points of different boundaries are needed to control and guarantee the local environment. As indicated by Akkas (2017), an IoT-based model was proposed to screen the nurseries where MicaZ hubs were utilized to quantify within boundaries like humidity, light, temperature, and pressing factor.

The world necessities more grounds for farming to satisfy the expanded food requests, yet the truth is that $33 \%$ arable land was in the last forty years because of disintegration and 
contamination (Cameroon et al., 2015). Lamentably, current farming methods dependent on modern cultivating are harming the dirt quality far quicker than nature can remake it. Generally speaking, it is assessed that disintegration rates from developed fields is 10 to multiple times more noteworthy than the formation of soil rates (Vadlamudi, 2017; Cameroon et al., 2015). Considering the decrease of arable land issues, it very well may be a fiasco for food creation soon with esent farming practices. Besides, as prior referenced, 70 percent of new water is just utilized for the purpose of agriculture, which can expand the weight on existing restricted water repositories. Vertical Farming (VF) is a response to address the difficulties of land and water deficiencies.

One of the handful few progressed strategies which is under experimentation to additional upgrade the harvest abilities by controlling their limits with the assistance of advanced detecting and correspondence advancements is Phenotyping. It depends on arising crop designing, which connects plant genomics with its ecophysiology and agronomy. (Ayaz et al., 2019)

Applying IoT to brilliant agriculture enhances the solutions of the numerous customary cultivating problems, similar to drought reaction, yield advancement, land reasonableness, water system, and vermin control.

The numerous tasks done in modern, large-scale agriculture is quite different from how it was done in ancient farming because most of the tasks are now done by heavy and complex equipment, such as: tractors, harvesters and other robots which are fully or partially supported by remote sensing and other communication technologies.

In accuracy farming, when activities like planting, fertilizing, water system, and reaping are played out, the working vehicles are outfitted with GPS and GIS equipment so they can work unequivocally, site-explicitly, and independently (Ayaz et al., 2019)

Amidst all the facilities for smart cultivating at present accessible on the lookout, remote sensors are the most pivotal and assume a key part with regards to gathering the state of the yield and other data. Remote sensors are getting utilized independent any place required, further incorporated with pretty much segment of advanced farming devices and large equipment, depending on application prerequisites (Ayaz et al., 2019).

Acoustic sensors offer a random apparatus in the management of farm, including soil development, weeding, organic product reaping, and so forth; the most benefit of this innovation is its minimal effort solutions with quick reaction, particularly while thinking about compact hardware. It works by estimating the adjustment in the clamor level as the apparatus connects with different materials, e.g., particles of soil (Kong et al., 2017). Acoustic sensors are regularly utilized for bug checking and discovery and ordering the seed assortments as indicated by their sound ingestion spectra.

FPGA based sensors are becoming popular in agriculture in recent years due to their flexibility of reconfiguration. The significant alternatives where these are regularly utilized incorporate estimating ongoing plant happening, water system, and humidity (Husni et al., 2018). However, their utilization in agriculture is within the early stages thanks to their limitations, like size, cost, and power consumption.

Optical sensors utilize light reflectance system that assists with estimating soil natural substances, soil dampness and shading, availability of minerals and their piece, content of clay, and so forth (Murray, 2018). They check the soil's capacity to reflect illumination 
dependent on various pieces of the electromagnetic range. The changes occurred in wave reflections help to point the changes in soil density and other parameters. (Ayaz et al., 2019) Based optical sensors fluorescence are utilized for fundamental plant appraisal, particularly to administer the crop development. Moreover, when integrating optical sensors with microwave scattering, it is often used for characterizing grove canopies, like olives and other similar crops.

These sorts of sensors are viewed as a decent decision in light of its cost viability, its assortment of utilizations and convenience and customizability. Basic uses are tank checking, splash distance estimation (e.g., blast tallness and width control to perform uniform spray inclusion, object discovery, and crash evasion), and observing yield covering (Dvorak et al., 2016; Alvarez et al., 2016; Vadlamudi, 2019). At the point when joined with a camera, these sensors are utilized for weed identification, where the statures of plants are distinguished utilizing the ultrasonic sensors and the camera decides the weed and harvest inclusion.

At the moment, there is no fully autonomous tractor available in market, but many researchers and manufactures are hardly working to mature the technology. Based on current progress and future demands of high-tech tractors, it is predicated that about 700,000 tractors equipped with facilities like auto steer or tractor guidance will be sold in 2028 (Agricultural Robots and Drones, 2019), while the same study expects that around 40,000 unmanned, fully-autonomous (level 5) tractors will be sold in 2038 (Agricultural Robots and Drones, 2019).

Reaping the harvest at the opportune time is exceptionally basic, carrying this out late or early can influence the crop produce altogether. When discussing the work, it is assessed that the US faces a $\$ 3.1$ billion decrease in the production of crop consistently because of work deficiency (Bronars, 2015). This, at the same time, as indicated by an investigation directed by the United States Department of Agriculture, generally speaking 14 percent of ranch costs go to wages and work costs, while it tends to be up to 39 percent in some work concentrated homesteads (Farm Labor, 2019). Considering the value of this level and work problems, ranch specialists expect that association of agriculture mechanical technology may facilitate the work pressure as well as give the adaptability to gather at whatever point required. To computerize the procedure of harvesting and make it more exact, the job of robots has been expanding in the present times (Bac et al, 2017) Considering the robot administrations, numerous analysts have done serious exploration to develop the affectability of natural product identification, its shape, size, shading, and confinement (Zhao et al., 2016; Zujevs et al., 2015).

Late years have seen quick extension of study, with specialists directing a developing number of studies and creating different models to feature the extent of cell phone plant apps. These researchers mostly belong to developing nations, as proposed systems are based primarily in countries like Kenya (Wyche \& Steinfield, 2016; Baumtiler, 2015), Ghana (Hidrobo \& Gilligan, 2017; Barnett et al, 2019), Nigeria (Adioet al., 2016; Koyenikan \& Ighoro, 2015), Mali (Sousa et al., 2019), Uganda (Nakato \& Beed, 2016), and Zimbabwe (Masukaet al., 2016). Albeit, the extent of cell phone use in agribusiness has been more usually noticed in Africa, tests in nations like China (Qian et al., 2015; Yu et al., 2017) Turkey (Isik et al., 2017; Guler et al.,2017), and India (Fu and Akter, 2016) are likewise expanding. Dissecting the accomplishment of $\mathrm{m}$-administrations relies upon numerous variables. One of the most comprehensive studies regarding the use of mobile phones for various 
agriculture applications was conducted to review all the important factors (Baumuller, 2018).

Venkatesh et al. presented their influential model for the acceptance and use of technology after studying eight models of technology adoption within the information technology domain. (Venkatesh et al, 2003). The studied models which were incorporated into their final model are Theory of Reasoned Action (TRA), Technology Acceptance Model (TAM), the Motivational Model (MM), Theory of Planned Behavior (TPB), the PC Utilization Model, Combined TAM and TPB (CTAM-TBP), Innovation Diffusion Theory and Social Cognitive Theory.

The UTAUT model was not only tested within different geographical contexts but also it was contextualized within numerous technology acceptance fields which are ranging from mobile wallet, (Dwivedi et al, 2016) open government data, mobile health, mobile learning to mobile banking, and mobile payment (Saeidi et al, 2020) Since UTAUT model was used in different researches in various technological arenas, it was proved that it could be a suitable contextualization tool for measuring the success and adoption of information technologies (Šumak \& Šorgo, 2016; Kalavani et al, 2018)

\section{Methodology}

\section{Study Population}

The study population for this research is the world in general. In 2018, agriculture accounted for $4 \%$ of global gross domestic product (GDP), and up to $25 \%$ of the GDP of some developing countries. (World Bank, 2020)

\section{Research Design}

This study used qualitative analysis. This kind of analysis employs subjective judgment. Only articles that were relevant to the scope of this study were used.

\section{Exclusion Criteria}

The following articles were excluded because of their irrelevance to this study: Articles not presenting new and emerging ideas, papers distributed other than meetings, diaries, licenses, and specialized reports, articles without characterizing information sources or where the information collection strategy was hazy, papers distributed before 2015, papers that are not pertinent to the hunt string.

\section{Sampling Technique and Sampling Size}

Purposive sampling was carried out because only articles relating to this subject matter were sampled. Credible sources like IEEE, Nanoscience, Sensors, etc. Nine articles and conference proceedings were sampled.

\section{Method of Data Collection and Analysis}

The data used for this study were gotten from online research and literature research. Analysis of the result was carried out using content analysis method. This is a tool used to determine the presence of certain words or concepts within some given qualitative data which are in text format. 


\section{ANALYSIS AND RESULTS}

\section{To examine recent developments in Internet of Things (IoT).}

The development of Internet of Things (IoT) innovation has prompted upgrade in sectors and businesses. Extracts from the qualitative study revealed that work is been modified and enhanced since the emergence of Internet of Things (IoT). This is evident from the excerpts that:

"....Internet of Things (IoT) is serving to be a promising innovation in numerous areas and enterprises proffering an approach to upgrade the client's insight and capacity by altering the workplace"

Source: IEEE

Also, it was revealed that inefficiencies and performance rate in sectors and industries can be tackled with Internet of Things (IoT). This is noted from the excerpts that:

"......the Internet-of-Things (IoT) is starting to affect a wide exhibit of areas and ventures, going from assembling, wellbeing, correspondences, and energy to the farming business, to lessen failures and improve the presentation across all business sectors......"

Source: Sensors

Also, IoT can be utilized anyplace in computerization, horticulture, controlling, and including observing of any genuine article, which exists in reality.

"Web of Things (IoT) is a component wherein objects (living and nonliving) are planned with some special metadata or identifiers. The meaning of this planning is the transmission of information over the web with no mediation of people with PCs or people with people or the other way around. IoT is an arising field these days and that can be utilized anyplace in computerization, agribusiness, controlling just as observing of any genuine article, which exists in reality. The fundamental point of IoT is for the most part bind together all that exists in this genuine world under a typical foundation. It will give us controlling over such items, however it will likewise educate us about the present status regarding these objects".

Source: IJSRTM

In summary, developments in Internet of Things (IoT) has greatly helped and improved all sectors and industries.

\section{To make comparison between Traditional and Smart Agriculture.}

Implementation of Smart Agriculture has brought a drastic change to Traditional farming. The findings revealed that practices of smart agriculture enhance the solutions of the many traditional farming issues.

"By implementing the latest sensing and IoT technologies in agriculture practices, every aspect of traditional farming method can be fundamentally changed. As of now, consistent reconciliation of remote sensors and the IoT in keen horticulture can raise farming to levels which were beforehand inconceivable. By.... practice of smart agriculture, IoT can assist with improving the arrangements of the numerous conventional cultivating issues, similar to dry season reaction, crop improvement, land appropriateness, water system, and vermin control".

Source: IJESC 
Also, IoT has provided an efficient pest management technique. The study revealed that IoT based intelligent devices are allowing the growers to slash pesticide uses significantly compared to the crude use of pesticides which are harmful to human and animal health, leaving severe, even irreversible, impact to the environment, ultimately causing significant contamination to entire ecosystems.

“......IoT based clever gadgets, like remote sensors, drones and robots are permitting the cultivators to cut pesticide utilizes fundamentally by absolutely spotting crop adversaries. Contrasted with conventional schedule or solution based bug control techniques, current IoT-based pest management gives constant observing, modeling, sickness guaging, consequently demonstrating more viably...."

\section{Source: Nanoscience}

It is now seen that precision agriculture is the new face of agriculture. This modern farming practice can bring a new age of green revolution and will be a new path towards development for countries where agriculture is the primary industry and the economy depends on it.

\section{To assess the role of Internet of Things (IoT) in Smart Agriculture.}

In smart agriculture, emergence of IoT is considered as a solution to needs in agriculture. It was revealed from the study that IoT is used at different levels in agriculture production.

"IoT usage in agribusiness is viewed as the ideal arrangement on the grounds that in this space there is a requirement for ceaseless checking and controlling. In the area of agriculture, IoT is utilized at various levels in the farming modern production chain. The fundamental uses of IoT in agribusiness are Precision Farming, Livestock, and Greenhouses......"

Source: In Proceedings of 2013 Future Network Mobile Summit

IoT is the use of present day ICT (Information and Communication Technologies) into farming. The study revealed that on IOT technologies will enhance productivity.

“......New smart cultivating methods dependent on IOT innovations will empower the farming business to decrease waste and improve efficiency In IOT based smart agriculture, a system is worked for checking the yield field with the help of sensors (light, moistness, temperature, soil moistness, etc). Farmers will be able to check the state of the field from anyplace".

\section{Source:IRJET}

IoT proposed a novel procedure for smart cultivating by connecting smart detecting and water system framework through remote correspondence innovation. Findings from this study revealed that lowcost sensor network technique and automated irrigation system can be achieved.

"IoT..., targets in making farming smart and present day utilizing computerization and IoT advancements. It gives an ease and powerful remote sensor network strategy to gain the dirt dampness and temperature from different area of ranch and according to the need of harvest regulator, choose whether the water system is empowered or not. It proposes a thought regarding how mechanized water system framework....."

Source: MDPI 
Also, it was revealed that Fertilization under smart agriculture helps to precisely estimate the required dose of nutrients.

"New IoT-based preparing approaches help to appraise the spatial examples of supplements necessities with a higher exactness and least work prerequisites. For instance, the Normalized Difference Vegetation Index (NDVI) utilizes aeronautical/satellite pictures to observe crop supplement status. Fundamentally, NDVI depends on the impression of noticeable and close infrared light from vegetation and is utilized to appraise the yield wellbeing, vegetation power, and thickness, further adding to evaluate the soil supplement level. Such exact execution can altogether improve the compost effectiveness, at the same time decreasing the results to the climate".

Source: Agricultural Engineering, vol. 56, no. 3.

Conclusively, the implementation of IoT-based Smart Agriculture has greatly helped to make agriculture smarter and more efficient to meet the further expectations.

\section{SUMmARY AND CONCLUSION}

The development of Internet of Things (IoT) innovation has prompted upgrade in sectors and businesses. It was also revealed from this study that inefficiencies and performance rate in sectors and industries can be tackled with Internet of Things (IoT). In addition, IoT can be used anywhere in automation, agriculture, controlling as well as monitoring of any real object, which exists in the real world. Implementation of Smart Agriculture has brought a drastic change to Traditional farming. The findings revealed that practices of smart agriculture enhance the solutions of the many traditional farming issues. Also, IoT has provided an efficient pest management technique.

In smart agriculture, emergence of IoT is considered as a solution to needs in agriculture. It was revealed from the study that IoT is used at different levels in agriculture production. IoT is the use of present day ICT (Information and Communication Technologies) into farming. IoT proposed a novel technique for smart cultivating by connecting keen detecting and water system framework through remote correspondence innovation. Also, it was revealed that Fertilization under smart agriculture helps to precisely estimate the required dose of nutrients.

This study showed that developments in Internet of Things (IoT) has greatly helped and improved all sectors and industries. It is now seen that precision agriculture is the new face of agriculture. This modern farming practice can bring a new age of green revolution and will be a new path towards development for countries where agriculture is the primary industry and the economy depends on it. Conclusively, the implementation of IoT-based Smart Agriculture has greatly helped to make agriculture smarter and more efficient to meet the further expectations.

\section{RECOMMENDATION}

Below are the recommendations made based on the findings in this study:

1. Scalability in technology should be encouraged; that is adding of newer devices over the existing infrastructure without affecting the functionality 
2. Since farming applications refer to wide geographical areas, then the architecture should be widely deployed in all countries

\section{REFERENCES}

Adio E. O., Abu Y., YUsuf S. K., and Nansoh S., (2016). Use of agricultural information sources and services by farmers for improve productivity in Kwara state. Library Phil. Pract. (e-J)

Agricultural Robots and Drones to Become a 45 Billion Dollar Industry by 2038. Accessed online: Apr. 15, 2019.

Ahmed, A. A. A., Donepudi, P. K., \& Asadullah, A. B. M. (2020). Artificial Intelligence in Clinical Genomics and Healthcare. European Journal of Molecular \& Clinical Medicine, 7(11), 1194-1202, https:/ / ejmcm.com/? action=article\&au $=24014$

Akka M. A. \& Sokullu R., (2017). An IoT-based greenhouse monitoring system with Micaz motes. Procedia Comput. Sci., vol. 113, pp. 603_608.

Álvarez-Arenas T. G., Gil-Pelegrin E., Cuello J. E., Fariñas M. D., Sancho-Knapik D., Burbano D. A. C., and Peguero-Pina J. J., (2016). Ultrasonic sensing of plant water needs for agriculture. Sensors, vol. 16, no. 7, p. 1089.

Antony, A. P., Leith, K., Jolley, C., Lu, J., \& Sweeney, D. J. (2020). A Review of Practice and Implementation of the Internet of Things (IoT) for Smallholder Agriculture. 1-19.

Ayaz, M., Member, S., \& Member, M. A. S. (2019). Internet-of-Things (IoT) based Smart Agriculture: Towards Making the Fields Talk. XX. https://doi.org/10.1109/ACCESS.2019.2932609

Ayaz, M.; Ammad-Uddin, M.; Sharif, Z.; Mansour, A.; Aggoune, E.-H.M. (2019). Internet-of-Things (IoT)-Based Smart Agriculture: Toward Making the Fields Talk. IEEE Access, 7, 129551-129583.

Bac C. W., Hemming J., van Tuijl B. A. J., Barth R., Wais E., and van Henten E. J., (2017). Performance evaluation of a harvesting robot for sweet pepper. J. Field Robot., vol. 34, no. 6, pp. 1123_1139.

Barnett I., Faith B., Gordon J., and Sefa-Nyarko C., (2019). External evaluation of mobile phone technology-based nutrition and agriculture advisory services in Africa and South Asia. Mobile Phones, Agricult., Nutrition Ghana, Qualitative Midline Study Rep. Brighton, Tech. Rep.

Baumüller H., (2015) "Agricultural innovation and service delivery through mobile phones analyses in kenya," Ph.D. dissertation, Fac. Agricult., Univ. Bonn, Bonn, Germany.

Baumüller H., (2018). The little we know: An exploratory literature review on the utility of mobile phone-enabled services for smallholder farmers. J. Int. Develop., vol. 30, no. 1, pp. 134_154.

BBC. (2019). The High-Tech Farming Revolution; BBC World News: London, UK.

Bronars S. G., (2015). A vanishing breed: How the decline in U.S. Farm laborers over the last decade has hurt the U.S. economy and slowed production on American farms. New American Economy, Tech. Rep.

Cameron D., Osborne C., Horton P., and Sinclair M., (2015). A sustainable model for intensive agriculture. Univ. Shef_eld, Shef_eld, U.K., Tech. Rep.

Chung S.-O., Choi M.-C., Lee, K.-H. Kim Y.-J., Hong S.-J., and Li M (2016.). Sensing technologies for grain crop yield monitoring systems: A review. J. Biosyst. Eng., vol. 41, no. 4, pp. 408_417,

Donepudi, P. K. (2020). Reinforcement Learning for Robotic Grasping and Manipulation: A Review. Asia Pacific Journal of Energy and Environment, 7(2), 69-78. https://doi.org/10.18034/apjee.v7i2.526

Donepudi, P. K., Ahmed, A. A. A., Hossain, M. A., \& Maria, P. (2020). Perceptions of RAIA Introduction by Employees on Employability and Work Satisfaction in the Modern Agriculture Sector. International Journal of Modern Agriculture, 9(4), 486-497. https://doi.org/10.5281/zenodo.4428205 
Dvorak J. S., Stone M. L., and Self K. P., (2016). Object detection for agricultural and construction environments using an ultrasonic sensor. J. Agricult. Saf. Health, vol. 22, no. 2, pp. 107_119.

Dwivedi Y.K., Shareef M.A., Simintiras A.C., Lal B., Weerakkody V., (2016). A generalized adoption model for services: a cross-country comparison of mobile health (mhealth). Govern. Inf. Quart. 33 (1)74-187

E. Sisinni, A. Saifullah, S. Han, U. Jennehag and M. Gidlund. (2018). Industrial Internet of Things: Challenges, Opportunities, and Directions, in IEEE Transactions on Industrial Informatics, vol. 14, no. 11, pp. 4724-4734, Nov. 2018.

Farm Labor. Accessed: Apr. 20, 2019. [Online].

Farooq, M. S., Riaz, S., Abid, A., Umer, T., \&Zikria, Y. Bin. (2020). Role of IoT Technology in Agriculture : A Systematic Literature Review.

Fu X. and Akter S., (2016). The impact of mobile phone technology on agricultural extension services delivery: Evidence from India. J. Develop. Stud., vol. 52, no. 11, pp. 1561_1576.

Gray, B.; Babcock, L.; Tobias, L.; McCord, M.; Herrera, A.; Cadavid, R. (2018). Digital Farmer Profiles: Reimagining Smallholder Agriculture; Grameen Foundation: Washington, DC, USA.

Guler E., Sengel T. Y., Gumus Z. P., Arslan M., Coskunol H., Timur S., and Yagci Y., (2017). Mobile phone sensing of Cocaine in a lateral flow assay combined with a biomimetic material. Anal. Chem., vol. 89, no. 18, pp. 9629_9632.

Hidrobo M. and Gilligan D., (2017). Using quantitative methods to evaluate mobile phone technology based nutrition and agriculture advisory services in Ghana. Brighton, U.K., Tech. Rep.

Hoogeveen M., Ono Y., Pfister S., Boulay A.-M., Berger M., Nansai K., Tahara K., Itsubo N., \& Inaba A. (2018). Consistent characterization factors at midpoint and endpoint relevant to agricultural water scarcity arising from freshwater consumption. Int. J Life Cycle Assessment, vol. 23, no. 12, pp. 2276_2287, doi: 10.1007/s11367-014-0811-5.

Husni M. I., Hussein M. K. , ZainaM. S. B. 1, Hamzah A., Nor D. M., and Poad H., (2018). Soil moisture monitoring using _eld programmable gate array. Indonesian J. Elect. Eng. Comput. Sci., vol. 11, no. 1,pp. 169_174.

K. Al-Saeidi, M. Al-Emran, T. Ramayah, E. Abusham, (2020). Developing a general extended UTAUT model for M-payment adoption. Technology in Society 62, 101293. https://doi.org/10.1016/j.techsoc.2020.101293

Kalavani A., Kazerani M., Shekofteh M., (2018). Acceptance of Evidence based medicine (EBM) databases by Iranian medical residents using unified theory of acceptance and use of technology (UTAUT), Health Policy and Technology, 7(3), 287-92. https://doi.org/10.1016/j.hlpt.2018.06.00553

Kong Q., Chen H., Mo Y. L., and Song G., (2017). Real-time monitoring of water content in sandy soil using shear mode piezoceramic transducers and active sensing: A feasibility study. Sensors, vol. 17, no. 10, p. 2395.

Koyenikan M. J. and Ighoro A., (2015). Farmers' use of mobile phone-based services for accessing agriculture and rural development information in northern zone of Edo State, Nigeria. Nigerian J. Rural Sociology, vol. 16, no. 2, pp. 23_28.

M. Ayaz, M. Ammad-uddin, I. Baig and e. M. (2018). Aggoune, "Wireless Sensor's Civil Applications, Prototypes, and Future Integration Possibilities: A Review. in IEEE Sensors Journal, vol. 18, no. 1, pp. 4-30, 1 Jan.1, 2018.

M. Ayaz, M. Ammad-Uddin, I. Baig, and E.-H. M. Aggoune, (2018). Wireless sensor's civil applications, prototypes, and future integration possibilities: A review. IEEE Sensors J., vol. 18, no. 1, pp. 4_30.

Masuka B., Matenda T., Chipomho J., Mapope N., Mupeti S., Tatsvarei S., and Ngezimana W., (2016). Mobile phone use by small-scale farmers: A potential to transform production and marketing in Zimbabwe. South Afr. J. Agricult. Extension, vol. 44, no. 2, pp. 121_135. 
Medela, A.; Cendón, B.; González, L.; Crespo, R.; Nevares, I. (2013). IoT multiplatform networking to monitor and control wineries and vineyards. In Proceedings of the 2013 Future Network Mobile Summit, Lisboa, Portugal, 3-5 July 2013; pp. 1-10.

Muhammad Ayaz, Mohammad Ammad-uddin, Zubair Sharif, Ali Mansour, and el-Hadi M. Aggoune (2019). Internet-of-Things (IoT) based Smart Agriculture: Towards Making the Fields Talk. 10.1109/ ACCESS.2019.2932609, IEEE Access

Murray S. C., (2018). Optical sensors advancing precision in agricultural production. Photon. Spectra, vol. 51, no. 6, p. 48.

Nakato G. V., Beed F., Bouwmeester H., Ramathani I., Mpiira S., Kubiriba J., and Nanavati S., (2016). Building agricultural networks of farmers and scientists via mobile phones: Case study of banana disease surveillance in Uganda. Can. J. Plant Pathol., vol. 38, no.3, pp. 307_316.

Nzie J. R. M., Bidogeza J. C., and Ngum N. A., (2017). Mobile phone use, transaction costs, and price: Evidence from rural vegetable farmers in Cameroon. J. Afr. Bus., vol. 19, pp. 323_342,

O. Elijah, T. A. Rahman, I. Orikumhi, C. Y. Leow and M. N. Hindia, (2018). An Overview of Internet of Things (IoT) and Data Analytics in Agriculture: Benefits and Challenges. in IEEE Internet of Things Journal, vol. 5, no. 5, pp. 3758-3773, Oct. 2018.

Oliveira K. V. de, Castelli H. M. E., Montebeller S. J., \& Avancini T. G. P., (2017). Wireless sensor network for smart agriculture using ZigBee protocol. in Proc. IEEE 1st Summer School Smart Cities (S3C), Natal, Brazil, Aug. 2017, pp.61_66.

Qian J.-P., Yang X.-T., Wu X.-M., Xing B., Wu B.-G., and Li M., (2015). Farm and environment information bidirectional acquisition system with individual tree identi_cation using smartphones for orchard precision management. Comput. Electron. Agricult., vol. 116, pp. 101_108.

Ratnaparkhi, S., Khan, S., Arya, C., Khapre, S., \& Singh, P. (2020). Materials Today : Proceedings Smart agriculture sensors in IOT: A review. Materials Today: Proceedings, $x x x x$. https://doi.org/10.1016/j.matpr.2020.11.138

S. Navulur, A.S.C.S. Sastry, M. N. (2017). Giri Prasad, "Agricultural Management through Wireless Sensors and Internet of Things" International Journal of Electrical and Computer Engineering (IJECE), 2017; 7(6) :3492-3499.

Sales, Nelson, Orlando, R. \& Artur, A. (2015). Wireless sensor and actuator system for smart irrigation on the cloud. IEEE 2nd World Forum on Internet of Things (WF-IoT). https://doi.org/10.1109/WF-IoT.2015.7389138

Shamshiri R. R, Kalantari F., Ting K. C., Thorp K. R., Hameed I. A., Weltzien C., Ahmad D., and Shad Z. M., (2018). Advances in greenhouse automation and controlled environment agriculture: A transition to plant factories and urban agriculture. Int. J. Agricult. Biol. Eng., vol. 11, no. 1,pp. 1_22.

Smart-Farming-Market-to-Reach-23-14-Billion-by-2022.html

Sönmez M. F. I_k, Y., lmaz C. Y_, Özdemir V., and lmaz E. N. Y, (2017). Precision irrigation system (PIS) using sensor network technology integrated with IOS/Android application. Appl. Sci., vol. 7, no. 9, p. 891.

Sousa F., Nicolay G., and Home R., (2019). Video on mobile phones as an effective way to promote sustainable practices by facilitating innovation uptake in mali. Int. J. Sustain. Develop. Res., vol. 5, no. 1, pp.1_8.

Srivastava, R., Sharma, V., Jaiswal, V., Raj, S., Tech, B., Krishna, C. S. E., College, E., \& Pradesh, U. (2020). A RESEARCH PAPER ON SMART AGRICULTURE USING IOT. July, 2708-2710.

Šumak B., Šorgo A., (2016). The acceptance and use of interactive whiteboards among teachers: differences in UTAUT determinants between pre- and post-adopters. Comput Hum Behav, 64, 602-20. https://doi.org/10.1016/j.chb.2016.07.037 
Vadlamudi, S. (2016). What Impact does Internet of Things have on Project Management in Project based Firms?. Asian Business Review, 6(3), 179-186. https://doi.org/10.18034/abr.v6i3.520

Vadlamudi, S. (2017). Stock Market Prediction using Machine Learning: A Systematic Literature Review. American Journal of Trade and Policy, 4(3), 123-128. https://doi.org/10.18034/ajtp.v4i3.521

Vadlamudi, S. (2019). How Artificial Intelligence Improves Agricultural Productivity and Sustainability: A Global Thematic Analysis. Asia Pacific Journal of Energy and Environment, 6(2), 91100. https://doi.org/10.18034/apjee.v6i2.542

Venkatesh V. Morris M., Davis G., Davis F., (2003). User acceptance of information technology: Toward a unified view, MIS Quarterly, 27(3) (2003) 425-478. https:/ / doi.org/10.2307/30036540

Water for Sustainable Food and Agriculture by FAO. Accessed: Apr. 15, 2019. Available: https://www.fao.org/3/a-i7959e.pdf

Wietzke A., Westphal C., Gras P., Kraft M., Pfohl K., Karlovsky P., Pawelzik E., Tscharntke T., and Smit I., (2018). Insect pollination as a key factor for strawberry physiology and marketable fruit quality, Agricult., Ecosyst. Environ., vol. 258, pp. 197_204,.

World Bank, CIAT and CATIE. 2015. Climate-smart agriculture in Peru. CSA country profiles for Latin America series. Washington, DC: The World Bank Group.

Wyche S. and Steinfield C., (2016). Why don't farmers use cell phones to access market prices? Technology affordances and barriers to market information services adoption in rural Kenya. Inf. Technol. Develop., vol. 22, no. 2, pp. 320_333.

Yu Q., Shi Y., Tang H., Yang P., Xie A., Liu B., and Wu W., (2017). eFarm: A tool for better observing agricultural land systems. Sensors, vol. 17, no. 3, p. 453.

Zhao Y., Gong L., Huang Y., and Liu C., (2016). A review of key techniques of vision-based control for harvesting robot. Comput. Electron. Agricult., vol. 127, pp. 311_323.

Zujevs A., Osadcuks V., and Ahrendt P., (2015). Trends in robotic sensor technologies for fruit harvesting: 2010-2015. Procedia Comput. Sci., vol. 77, pp. 227_233.

\section{How to Cite:}

Vadlamudi, S. (2020). Internet of Things (IoT) in Agriculture: The Idea of Making the Fields Talk. Engineering International, 8(2), 87-100. https://doi.org/10.18034/ei.v8i2.522 